\title{
Health Profession Student Perception on Hookah Use and Curriculum Improvement Implications
}

\author{
Loewen JM'1 Savaya MG $^{2}$ and Mackie $\mathrm{ZF}^{2}$
}

${ }^{1}$ Department of Patient Management, University of Detroit Mercy School of Dentistry, USA

${ }^{2}$ University of Detroit Mercy School of Dentistry, USA

\begin{abstract}
Hookah smoking has become a popular way for young people to socialize and relax. Studies have identified harmful health consequences as a result of hookah usage. Little is known about the knowledge future healthcare providers have about this fairly new trend. This study assessed the knowledge of students in health professions programs on hookah usage to determine possible curriculum needs. With appropriate education, these future healthcare providers have the opportunity to influence patients to reduce and prevent the use of hookah. In the fall term of 2011, a voluntary online survey containing twenty items was conducted at seven participating health professions programs. Nearly half of respondents were unsure about harmful health consequences associated with hookah usage. When asked if the amount of tar and nicotine exposure during a hookah session was about the same compared to a pack of cigarettes, the majority of those surveyed were unsure. Those reporting current use of hookah believed it was possible to stop at any time, suggesting that they are uninformed about the addictive nature of this form of tobacco use. A lack of knowledge about the harmful health effects of hookah was revealed. Along with adequate training about all forms of tobacco, further training in health professions programs about health effects of the use of hookah needs to be implemented so that patients can be appropriately advised and assisted.
\end{abstract}

Keywords: Hookah; Tobacco; Dental education; Health care (professions) programs; Dental student

\section{Introduction}

Smoking tobacco with use of the hookah, also known as waterpipe, shisha, boory, arghileh, goza, hubble bubble and narghile, has been increasing in popularity among teens and young adults. The use among college students has been found to be for the purpose of socializing and relaxation [1]. With hookah lounges (also known as cafés or bars) opening up across the United States to accommodate engaging in this activity, more students are being introduced to the trend of gathering with friends and socializing while passing around a hookah. The increase in the number of lounges is associated with increased usage among high school students and college students [2].This increase is a concern due to the user's lack of knowledge about the associated health risks. The aims of this study included to 1) provide a brief history of hookah use including the rise in popularity among young people in the US, 2) analyze results of our survey about hookah use among health professions program students, and 3) determine how these study findings could potentially be used to enhance curriculum content on the health consequences of the various types of tobacco usage [3]. Hookah smoking has been described as first becoming widely used in the Middle East and Asia in the fifteenth century [4]. A decline in use was experienced in the $20^{\text {th }}$ century and then popularity escalated in the nineties. Since then, this trend has emerged in the US, and its popularity and prevalence has spread throughout the country, especially among young people and college students [4-9]. Due to the way some state laws have been written, use of hookah and hookah smoking have been found to be unaddressed or exempted from smokefree air laws. Rationale for exemption has included classification as a retail tobacco establishment or tobacco bar/cigar lounge and if compliance may cause economic devastation to a business [4,6]. The design of the hookah consists of a bowl at the very top, which serves as a compartment for the flavored tobacco and charcoal. Another part of the design includes a tray into which coal debris is collected. The base portion of a hookah holds the water. Attached to the base is a one way air valve to allow excess smoke to exit the base. A hose socket on the other end of the base holds the hose, which is the area where tobacco travels through, into a mouthpiece that enables users to inhale the tobacco (Figure 1). Studies have shown that sharing the mouthpiece of this device is a risk factor for transmission of diseases such as tuberculosis, herpes, and hepatitis [10]. Specifically, studies have recommended that the use of water pipes be included in the routine search for carriers of infection due to an increased risk among users [11].

There are several factors of hookah usage which allow users to believe that hookah is more acceptable and less harmful than cigarette smoking. Typically no health warnings appear on the packaging of the tobacco used for hookah smoking, as is found on cigarette and other tobacco packaging, misleading users into believing there is no harm, or that the harm is negligible [12]. The attraction of fruit-flavored smoke found with this form of tobacco, affordability, and the associated social appeal all contribute to increased consumption and the belief of a decreased health risk $[7,13]$. The main desire for hookah is the flavor. The aroma entices users to try hookah, and the sweet taste and lack of offensive odor typically associated with cigarette smoking compels users to continue smoking hookah [14].

A study by Shahedah and Saleh analyzed the amount of tar, nicotine, carbon monoxide, and various other chemicals present in hookah as compared to cigarettes (Table 1) [15]. In 2005, a World Health

*Corresponding author: Jill M Loewen, Clinical Associate Professor, Departmen of Patient Management, University of Detroit Mercy School of Dentistry, 2700 Martin Luther King Jr. Blvd. Detroit, MI 48208, USA, Tel: 313-494-6633; E-mail: loewenjm@udmercy.edussssss

Received January 22, 2016; Accepted February 01, 2016; Published February 07, 2016

Citation: Loewen JM, Savaya MG, Mackie ZF (2016) Health Profession Studen Perception on Hookah Use and Curriculum Improvement Implications. Health Care: Current Reviews 4: 157. doi: 10.4172/2375-4273.1000157

Copyright: (c) 2016 Loewen JM, et al. This is an open-access article distributed under the terms of the Creative Commons Attribution License, which permits unrestricted use, distribution, and reproduction in any medium, provided the original author and source are credited. 


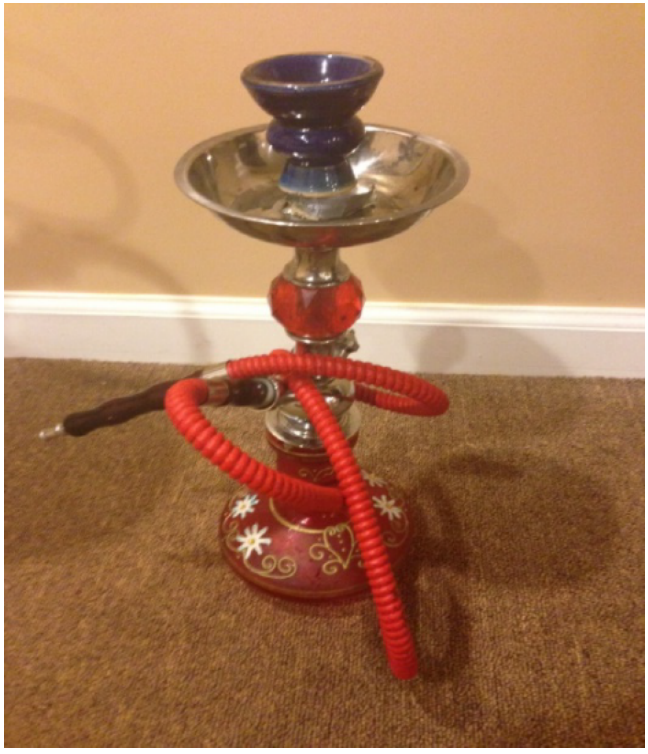

Figure 1: Hookah.

\begin{tabular}{|c|c|c|c|}
\hline $\begin{array}{c}\text { Component in } \\
\text { tobacco }\end{array}$ & $\begin{array}{c}\text { Smoke produced } \\
\text { from 10 gm } \\
\text { hookah tobacco }\end{array}$ & $\begin{array}{c}\text { Smoke } \\
\text { produced from 1 1 } \\
\text { cigarette }\end{array}$ & $\begin{array}{c}\text { Hookah smoke } \\
\text { produced compared } \\
\text { to cigarette smoke } \\
\text { produced }\end{array}$ \\
\hline Tar & 802 & $\begin{array}{c}\text { Range of 1-27 } \\
\text { Average 11.2 }\end{array}$ & $72 \mathrm{x}$ \\
\hline Nicotine & 2.96 & $\begin{array}{c}\text { Range of 0.1-2 } \\
\text { Average 0.77 }\end{array}$ & $4 \mathrm{x}$ \\
\hline $\begin{array}{c}\text { Carbon } \\
\text { Monoxide Co }\end{array}$ & 143 & $\begin{array}{c}\text { Range of 1-22 } \\
\text { Average 12.6 }\end{array}$ & $11 \mathrm{x}$ \\
\hline
\end{tabular}

Table 1: Chemicals found in hookah tobacco smoke compared to those found in cigarette smoke [34-36].

Organization (WHO) study group found that the smoker of hookah can inhale perhaps 100 times more in volume of smoke in one hookah session in comparison to that from smoking a single cigarette [8]. Other studies have demonstrated that the amount of nicotine consumed in one smoking session of hookah was of similar magnitude to smoking at least one to as many as fifty cigarettes. Furthermore, other findings revealed that one session of hookah smoking resulted in seventy two times the amount of tar, and up to eleven times the amount of carbon monoxide as compared to smoking one cigarette. ${ }^{15}$ Evidence has suggested that hookah smoke likely contains an abundance of several of the chemicals thought to be associated with elevated incidence of cancer and cardiovascular disease similar to the levels of risk found in cigarette smokers [15-17]. Lack of adequate knowledge of hookah smoking is distressing when considering potential health consequences as a result of use. Several studies have assessed the perceptions and knowledge of various groups. These studies have found that young people, even those who express disdain for cigarette smoking, see hookah smoking as "cool", "hip" and at low risk for harmful health consequences [18]. In one study, adolescents aged 14-19 were surveyed on knowledge and perception of hookah usage and then provided with a health awareness education session. The knowledge and perceptions assessed after this health awareness session showed improvement, especially regarding awareness about health hazards [19]. Results of the study could infer that appropriately educated health professionals who have access to youth could inform them and be influential regarding the possible health consequences.
Although several studies have evaluated young people and college students, our study assessed the perception, knowledge, and attitude about hookah use of health professions program students enrolled in dental, dental hygiene, medical, nursing, physician's assistant, pharmacy, and addiction studies programs to identify possible program needs for the implementation of further education on this topic. Due to what has been described as a surge in popularity of hookah use in recent years and indication as the "second global tobacco epidemic", it is a growing public health threat and has signaled a need to determine status of future healthcare provider knowledge $[9,20]$.

\section{Materials and Method}

The University of Detroit Mercy School of Dentistry researchers obtained IRB approval \#1112-07 with exempt status for this study. Survey questions were adapted from a survey instrument that assesses waterpipe (hookah) use designed by Maziak et al., who used literature review and tobacco researcher discussions to create the survey instrument. Since hookah use typically occurs on a less frequent basis than cigarette smoking, current use responses were assessed either as weekly (at least once a week but less than daily) or monthly (once a month but less than weekly) [21]. A survey using the online program SurveyGizmo ${ }^{\mathrm{TM}}$ was created. It consisted of twenty questions using both multiple choice and true/false item types. The email invitation sent to potential participants that contained the survey link assured their anonymity would be protected if they choose to participate. To assess clarity and appropriateness of the survey items prior to the launch, the survey was piloted to University of Detroit Mercy School of Dentistry program residents enrolled in Orthodontics, Endodontics, Periodontics and the Advanced Education in General Dentistry programs. Upon analysis of the results, the survey was improved and finalized for launch in early September 2011. A total of 2496 students that included two universities were invited to participate, representing medical, dental, dental hygiene, pharmacy, physician assistant, nursing, and addiction studies programs. Prior to the distribution of the survey, lead faculty of these programs were identified and asked to assist in survey administration by promoting the completion of the survey and distributing it though a forwarded email link to the students in their programs. With three reminder emails sent that followed the initial survey invitation and link, the survey remained open for 6 weeks. Both descriptive statistics and chi-square tests with significance at $\mathrm{p}<0.05$ were used to analyze the survey results.

\section{Results}

\section{Study sample}

A total of 424 respondents completed the online survey (Table 2). Displays the demographic characteristics of the sample. Overall, the sample was mostly white / Caucasian (67.9 percent), with Arab/ Chaldean being the second largest demographic contingent (13.2 percent). There were more female respondents (59.6 percent), and the vast majority of respondents were under age 30 (85.1 percent). Among the various health professions, medical school program students were the most frequent respondents (43.2 percent), followed by dental (23.1 percent), and nursing (15.8 percent), with all other health professions programs comprising less than 10 percent of the sample each. Over 86 percent of respondents were in the first 3 years of their program with a small number ( 13.7 percent) being in the $4^{\text {th }}$ year of their program.

\section{Use of hookah / tobacco products}

Demonstrates survey responses across all respondent characteristics. 
Citation: Loewen JM, Savaya MG, Mackie ZF (2016) Health Profession Student Perception on Hookah Use and Curriculum Improvement Implications. Health Care: Current Reviews 4: 157. doi: 10.4172/2375-4273.1000157

Page 3 of 6

\begin{tabular}{|l|c|c|}
\hline & Frequency & $\%$ \\
\hline Race & & \\
Black / African American & 15 & 3.5 \\
White / Caucasian & 288 & 67.9 \\
Asian & 27 & 6.4 \\
Asian Indian & 30 & 7.1 \\
Arab / Chaldean & 56 & 13.2 \\
Hispanic / Latino & 5 & 1.2 \\
American Indian & 1 & 0.2 \\
Native Hawaiian / Pacific Islander & 2 & 0.5 \\
\hline Gender & & \\
Male & 172 & 40.6 \\
Female & 252 & 59.6 \\
\hline Age & 151 & \\
18 to 23 & 210 & 35.6 \\
24 to 29 & 31 & 49.5 \\
30 to 35 & 32 & 7.3 \\
Over 35 & & 7.5 \\
\hline Program & 5 & 1.2 \\
Addiction Studies & 12 & 2.8 \\
Dental Hygiene & 98 & 23.1 \\
Dental Student & 183 & 43.2 \\
Med Student & 67 & 15.8 \\
Nursing & 26 & 6.1 \\
Pharmacy & 33 & 7.8 \\
Physician Assistant & 137 & \\
\hline Years in program & 58 & 32.3 \\
1 year or less & & 29.0 \\
2 years & & 13.0 \\
3 years & & \\
4 or more years & & \\
\hline
\end{tabular}

Table 2: Demographic statistics.

Among the 424 respondents, 55.4 percent $(n=235)$ reported that they had tried hookah at some point in their lives (Table 3). Among the 235 that had tried hookah, 18.7 percent $(n=44)$ indicated that they currently still use hookah. About 91percent $(n=40)$ of those that still use hookah indicated that they use it on a monthly basis and about 9 percent $(n=4)$ indicated that they use hookah on a weekly basis. Nearly 10 percent $(n=41)$ of all respondents were current cigarette smokers, and 7 percent $(n=30)$ used other tobacco products. Chi-square tests revealed that among current hookah users the rate of smoking cigarettes is 30 percent ( 13 of 44 ) higher than the cigarette smoking rate among non-users which was 12 percent (23 of 191); a statistically significant difference $(p=0.004)$. This difference was not present for the use of other types of tobacco $(\mathrm{p}=0.155)$.

Chi-square tests revealed that race/ethnicity was correlated with having used hookah at least once in the past $(\mathrm{p}<0.001)$ (Table 4$)$. Specifically, when compared to all other groups combined, those that self-identified as Asian ( $\mathrm{p}=0.047)$, and black/African American ( $\mathrm{p}$ $<0.001$ ) were significantly less likely to have used hookah in the past and respondents that self-identify as Arab/Chaldean were significantly more likely than other groups to have used hookah in the past ( $\mathrm{p}=$ 0.002). An increased rate of hookah use remains when looking at the rate of current users among Arab/Chaldean respondents (33.3 percent) compared to the rate of current users among all other racial groups combined (15.5 percent) and it is statistically significant $(\mathrm{p}=0.007)$.

There was no difference between males and females in likelihood of having used hookah $(p=0.184)$ while respondents under 30 years old were more likely to have tried hookah than those 30 years and older ( $p$ $<0.001)$.

The health professional program that a respondent was enrolled in also had a significant relationship with whether or not the respondent had ever used hookah $(p=0.013)$. Specifically, those enrolled in the

\begin{tabular}{|c|c|c|}
\hline Survey Item & Frequency & $\%$ \\
\hline $\begin{array}{l}\text { Ever smoked hookah? } \\
\text { Yes } \\
\text { No }\end{array}$ & $\begin{array}{l}235 \\
189\end{array}$ & $\begin{array}{l}55.4 \\
44.6\end{array}$ \\
\hline $\begin{array}{l}\text { Currently smoke hookah? }(n=235) \\
\text { Yes } \\
\text { No }\end{array}$ & $\begin{array}{c}44 \\
191\end{array}$ & $\begin{array}{l}18.7 \\
81.3\end{array}$ \\
\hline $\begin{array}{l}\text { Hookah use frequency }(n=44) \\
\text { Monthly } \\
\text { Weekly }\end{array}$ & $\begin{array}{c}40 \\
4\end{array}$ & $\begin{array}{c}90.9 \\
9.1\end{array}$ \\
\hline $\begin{array}{l}\text { Smoke cigarettes? } \\
\text { Yes } \\
\text { No }\end{array}$ & $\begin{array}{c}41 \\
383\end{array}$ & $\begin{array}{c}9.7 \\
90.3\end{array}$ \\
\hline $\begin{array}{l}\text { Use other tobacco? } \\
\text { Yes } \\
\text { No }\end{array}$ & $\begin{array}{c}30 \\
394\end{array}$ & $\begin{array}{c}7.1 \\
92.9\end{array}$ \\
\hline $\begin{array}{l}\text { Hookah smoking is safe use of tobacco } \\
\text { True } \\
\text { False } \\
\text { Unsure }\end{array}$ & $\begin{array}{c}30 \\
319 \\
75\end{array}$ & $\begin{array}{c}7.1 \\
75.2 \\
17.7\end{array}$ \\
\hline $\begin{array}{l}\text { Hookah smoking has an effect on oral health } \\
\text { True } \\
\text { False } \\
\text { Unsure }\end{array}$ & $\begin{array}{r}370 \\
13 \\
41\end{array}$ & $\begin{array}{l}87.3 \\
3.1 \\
9.7\end{array}$ \\
\hline $\begin{array}{l}\text { Minimal consequences associated with hookah use } \\
\text { True } \\
\text { False } \\
\text { Unsure }\end{array}$ & $\begin{array}{c}45 \\
242 \\
137\end{array}$ & $\begin{array}{l}10.6 \\
57.1 \\
32.3\end{array}$ \\
\hline $\begin{array}{l}\text { Would you decrease use if found to be harmful? }(n=44) \\
\text { Yes } \\
\text { No } \\
\text { Unsure }\end{array}$ & $\begin{array}{c}8 \\
23 \\
13\end{array}$ & $\begin{array}{l}18.2 \\
52.3 \\
29.5\end{array}$ \\
\hline $\begin{array}{l}\text { Concern about disease transmission? } \\
\text { Yes } \\
\text { No } \\
\text { Unsure }\end{array}$ & $\begin{array}{c}361 \\
24 \\
39\end{array}$ & $\begin{array}{r}85.1 \\
5.7 \\
9.2\end{array}$ \\
\hline $\begin{array}{l}\text { Fruit flavored hookah is healthier } \\
\text { True } \\
\text { False } \\
\text { Unsure }\end{array}$ & $\begin{array}{c}12 \\
357 \\
55\end{array}$ & $\begin{array}{l}2.8 \\
84.2 \\
13.0\end{array}$ \\
\hline $\begin{array}{l}45 \text { to } 50 \text { minute hookah session same as } 1 \text { pack cigarettes } \\
\text { True } \\
\text { False } \\
\text { Unsure }\end{array}$ & $\begin{array}{c}175 \\
36 \\
213\end{array}$ & $\begin{array}{c}41.3 \\
8.5 \\
50.2\end{array}$ \\
\hline $\begin{array}{l}\text { Can you quit at any time? }(n=44) \\
\text { Yes } \\
\text { No } \\
\text { Unsure }\end{array}$ & $\begin{array}{c}40 \\
2 \\
2\end{array}$ & $\begin{array}{c}90.9 \\
4.5 \\
4.5\end{array}$ \\
\hline $\begin{array}{l}\text { Would you advise patients against hookah use? } \\
\text { Yes } \\
\text { No } \\
\text { Unsure }\end{array}$ & $\begin{array}{c}357 \\
17 \\
50\end{array}$ & $\begin{array}{c}84.2 \\
4.0 \\
11.8\end{array}$ \\
\hline $\begin{array}{l}\text { Does hookah have negative impact on healthcare provider image? } \\
\text { Yes } \\
\text { No } \\
\text { Unsure }\end{array}$ & $\begin{array}{l}300 \\
80 \\
44\end{array}$ & $\begin{array}{l}70.8 \\
18.9 \\
10.4\end{array}$ \\
\hline
\end{tabular}

Table 3: Descriptive statistics for survey items.

dental program were more likely to have used hookah than those enrolled in other programs $(\mathrm{p}=0.007)$ while those enrolled in nursing ( $\mathrm{p}$ $=0.029)$ and PA $(\mathrm{p}=0.022)$ programs were less likely than respondents enrolled in other programs to have used hookah. However, those enrolled in the dental program (18.2 percent) do not differ significantly from non-dental program respondents (18.9 percent) in likelihood of reporting current use of hookah $(\mathrm{p}=0.894)$.

Heightened rates of having used hookah were observed among those self-identifying as Arab/Chaldean and among students in the dental program. A chi-square test was performed to determine whether 


\begin{tabular}{|c|c|c|c|c|c|}
\hline & Yes & & No & & \\
\hline & $n$ & $\%$ & $n$ & $\%$ & Overall p \\
\hline $\begin{array}{l}\text { Race } \\
\text { Black / African American } \\
\text { White / Caucasian } \\
\text { Asian } \\
\text { Asian Indian } \\
\text { Arab / Chaldean } \\
\text { Other }\end{array}$ & $\begin{array}{c}1 \\
156 \\
10 \\
20 \\
42 \\
6\end{array}$ & $\begin{array}{l}6.7 \\
54.2 \\
37.0 \\
66.7 \\
75.0 \\
75.0\end{array}$ & $\begin{array}{c}14 \\
132 \\
17 \\
10 \\
14 \\
2\end{array}$ & $\begin{array}{l}93.3 \\
45.8 \\
63.0 \\
33.3 \\
25.0 \\
25.0\end{array}$ & $<0.001^{*}$ \\
\hline $\begin{array}{l}\text { Gender } \\
\text { Male } \\
\text { Female }\end{array}$ & $\begin{array}{l}102 \\
133 \\
\end{array}$ & $\begin{array}{l}59.3 \\
52.8\end{array}$ & $\begin{array}{c}70 \\
119\end{array}$ & $\begin{array}{l}40.7 \\
47.2\end{array}$ & 0.184 \\
\hline $\begin{array}{l}\text { Age } \\
\text { Under } 30 \\
30 \text { and older }\end{array}$ & $\begin{array}{c}213 \\
22\end{array}$ & $\begin{array}{l}59.0 \\
34.9\end{array}$ & $\begin{array}{c}148 \\
41\end{array}$ & $\begin{array}{l}41.0 \\
65.1\end{array}$ & $<0.001^{*}$ \\
\hline $\begin{array}{l}\text { Program } \\
\text { Addiction Studies } \\
\text { Dental Hygiene } \\
\text { Dental Student } \\
\text { Med Student } \\
\text { Nursing } \\
\text { Pharmacy } \\
\text { Physician Assistant }\end{array}$ & $\begin{array}{c}2 \\
8 \\
66 \\
105 \\
29 \\
13 \\
12\end{array}$ & $\begin{array}{l}40.0 \\
66.7 \\
67.3 \\
57.4 \\
43.3 \\
50.0 \\
36.4\end{array}$ & $\begin{array}{c}3 \\
4 \\
32 \\
78 \\
38 \\
13 \\
21\end{array}$ & $\begin{array}{l}60.0 \\
33.3 \\
32.7 \\
42.6 \\
56.7 \\
50.0 \\
63.6\end{array}$ & $0.013^{*}$ \\
\hline $\begin{array}{l}\text { Years in program } \\
1 \text { year or less } \\
2 \text { years } \\
3 \text { years } \\
4 \text { or more years }\end{array}$ & $\begin{array}{l}74 \\
66 \\
63 \\
32\end{array}$ & $\begin{array}{l}54.0 \\
53.7 \\
59.4 \\
55.2\end{array}$ & $\begin{array}{l}63 \\
57 \\
43 \\
26\end{array}$ & $\begin{array}{l}46.0 \\
46.3 \\
40.6 \\
44.8\end{array}$ & 0.812 \\
\hline
\end{tabular}

Table 4: Respondent characteristics by whether or not they have ever smoked hookah.

or not there was a relationship between this race/ethnic identification and enrollment in the dental program. Among dental program students, 22 percent (22 of 98) identified as Arab/Chaldean while across all other health professions only 10 percent ( 34 of 326) identified themselves as Arab/Chaldean. This suggests that the difference in usage among dental program students may be partially explained by the increased numbers of Arab/Chaldeans in the dental program.

\section{Knowledge and attitudes about hookah}

Displays findings of knowledge and attitude items regarding hookah use (Table 3). Among the 424 respondents, 7 percent $(n=30)$ indicated that they believe hookah smoking is a safe use of tobacco, 75 percent $(\mathrm{n}=319)$ indicated that they believe it is unsafe, and 18 percent $(\mathrm{n}=$ 75) indicated that they were unsure of whether it was safe or not. Only 11 percent $(n=45)$ of respondents believed that there were minimal consequences associated with the use of hookah, 57 percent $(n=242)$ indicated a belief that the consequences were more than minimal, and 32 percent $(n=137)$ were unsure of whether the consequences are minimal. Additionally, 87 percent $(n=370)$ of respondents believed that hookah smoking has a significant effect on oral health, 85 percent $(\mathrm{n}=361)$ indicated that they have concerns about disease transmission with hookah, 84 percent $(n=357)$ indicated that they did not believe fruit flavored hookah to be healthier, 84 percent $(n=357)$ indicated that they would advise patients against using hookah, and 71 percent $(\mathrm{n}=300)$ felt that hookah use has a negative impact on the image of a healthcare provider.

Among knowledge and attitude items, current hookah users differed from non-users on the item regarding how they would advise patients about using hookah and on their beliefs about how hookah use affects their image as a healthcare provider. Only 61 percent $(n=27)$ of current hookah users indicated that they would advise patients not to use hookah, while 85 percent $(n=190)$ of non-users would advise patients against hookah use $(\mathrm{p}=0.001)$. Among current hookah users
25 percent $(n=11)$ believed that hookah use had a negative impact on their image as a healthcare provider. Among non-users the belief in a negative impact on their image was 66 percent $(n=137)$, a statistically significant difference $(\mathrm{p}<0.001)$.

When compared to cigarette smoking, just over 50 percent $(\mathrm{n}=$ 213) of respondents were unsure of whether a 45 to 50 minute hookah session has the same health effects as smoking one pack of cigarettes; 41 percent $(n=175)$ believed that it was the equivalent of smoking one pack of cigarettes and 9 percent $(n=36)$ believed that it was not the same as smoking one pack of cigarettes.

There were two items directed at current hookah users, 1) Would you decrease your hookah use if it was harmful to your health? And 2) Can you quit at any time? Among the 44 current users, only 18 percent $(n=8)$ indicated that they would decrease their use of hookah if it was harmful to their health and 91 percent $(n=40)$ of current users expressed a belief that they could quit at any time.

\section{Discussion}

Our study indicated that nearly half of respondents lacked appropriate knowledge of the harmful health effects of hookah. Because hookah lounges are becoming an increasingly acceptable means of socializing, this perpetuating issue is problematic for the health of all those using it or potentially even those who are exposed to the smoke. The CDC identified approximately 300 operating hookah lounges in the United States in 2006, with a continuing steady increase [3,4,8]. A search for more recent statistics found an online directory posting of 565 hookah bars and lounges [22].

The attitudes of the health professions students in our study were contradicting. Most of the respondents (84.2 percent) surveyed state that they would advise their patients not to use hookah, however survey results indicated they are not fully aware of the harmful health consequences. To adequately advise patients, appropriate knowledge of the topic is necessary. 91 percent of those who indicated current hookah use believed they could permanently quit the use of hookah at any time, suggesting they were not concerned about addiction potential. Over half of the respondents were also unaware of the amount of tar and nicotine in a 45-50 minute hookah session. Studies comparing the amount of nicotine in hookah as compared to cigarettes show that the amount of nicotine in one smoking session of hookah was of similar magnitude as what might be found with smoking approximately 20 cigarettes [16]. This high concentration of nicotine in hookah may create a gateway to smoking other forms of tobacco, such as cigarettes [23].

Almost all respondents believed that hookah smoking has an effect on oral health. Similarly, most responded fruit flavored hookah tobacco was not healthier than regular tobacco. Our survey findings revealed that these health professions program students demonstrated some belief that hookah smoking is harmful. Despite finding the students somewhat knowledgeable, the lack of adequate knowledge our findings revealed suggested a significant need for health professions program curriculum change and improvement.

Numerous research findings have revealed harmful health consequences yet the lack of adequate knowledge of the health consequences of hookah usage among its users is cause for concern [2]. The intent of this study was not meant to comprehensively investigate the health effects of hookah usage or to investigate specific curriculum content, rather to obtain a snapshot about the knowledge and perceptions of health professions program students, since they are on the front lines as future educators of our communities. 
A large number of studies have indicated there is a widespread lack of knowledge about the health consequences among high school and university students, with results demonstrating that these students were largely unaware [2,24-26]. With our findings, the uncertainty and misinformation of survey participants who will become future health professionals is disconcerting and should alert educators to evaluate tobacco use content and effectiveness in the program curricula.

Study findings from Project Leonardo reported by Ciccone et al in 2010, demonstrated the effective use of care managers, implemented into health care systems in Italy. Using care managers for the improvement of a patient's self-efficacy in managing their own health outcomes, particularly with the patient experiencing chronic disease, combined with a multidisciplinary approach that utilizes a team of health professionals to coordinate patient care can be a direction to patient care having the capacity to improve treatment for tobacco use patient education and dependence treatment [27]. These findings are closely aligned with training and treatment approaches reported in other studies. A number of studies indicate multiple health professionals addressing tobacco use as having the potential to greatly improve both quitting and readiness to quit as a resulting in more exposure to evidence-based treatment with more successful quitting attempts [28-30]. Although tobacco use has been widely designated as a chronic disease, the US health care system has not yet incorporated effective and consistent attention [31]. A recent study identified needed improvement of training in dental education programs on a global level, which could be transferrable to other health professions programs. In a recent study of multidisciplinary training programs conducted by Chen et al, support for large health care system access to that model was emphasized [32,33].

It is imperative to educate health professional students so that hookah users are identified and are provided with appropriate advice to halt continued hookah use and to ensure that prevention advice is given about ever starting to use hookah, which could prevent a gateway to the use of other forms of tobacco.

\section{Limitations}

This study relied on self-report, which traditionally carries potential limitations with results. Although greater student participation would be most effective, the researchers believed 424 student responses were significant to obtain a general overview about the knowledge and perceptions held by health professions program students. Future studies could consider offering an incentive to gain a larger number of survey participant responses. This study relied on each program administrator to forward the survey to students through emailed survey link. This resulted in loss of control on how this was carried out. Arrangements could be made that allows a closer link to the communication process carried out by the cooperating program administrators. A major strength of this study is the relevancy of the research topic as urgent, to bring awareness to educators regarding consideration and incorporation of content into the health professions program curriculum and additionally serves as a call to action for health professionals currently practicing, to seek additional training. Even greater impact could be achieved by investigating the curriculum in each program. There are other health professions programs that could be studied, important to this issue. To more widely investigate differences among the different health professions and investigate more specific differences in gender, race, ethnicity and age among health professions program students would be powerful in effecting change.

\section{Conclusion}

When the issue of hookah use as well as the use of other forms of tobacco is not addressed, it can be interpreted by a patient as a minimal health issue. Our study identified that health professions programs curricula needs to do more to increase awareness of this disconcerting trend. Inclusion of education into the curriculum that includes both prevention and treatment intervention of tobacco use of all types is needed. Health professions programs can be a source for further research on the health effects of hookah usage, effective health professions program curricula and to assist in the identification of effective intervention and treatment, and ultimately minimize the spread of this emerging public health threat.

\section{Acknowledgement}

The authors thank Michelle Wheatear, Ph.D., of University of Detroit Mercy School of Dentistry and Aaron J. Bonham, MS, of University of Missouri-Kansas City for their assistance with this project.

\section{References}

1. Braun RE, Glassman T, Wohlwend J, Whewell A, Reindl DM (2012) Hookah use among college students from a Midwest University. J Community Health 37: 294-298.

2. Smith JR, Novotny TE, Edland SD, Hofstetter CR, Lindsay SP, et al. (2011) Determinants of hookah use among high school students. Nicotine Tob Res 13: $565-572$.

3. American Lung Association (2011) Hookah smoking: a growing threat to public health. Smoke free Communities Project.

4. Nuzzo E, Shensa A, Kim KH, Fine MJ, Barnett TE, et al. (2013) Associations between hookah tobacco smoking knowledge and hookah smoking behavior among US college students. Health Educ Res 28: 92-100.

5. Jonson G, Jordan M (2013) Hookah history.

6. Primack BA, Hopkins M, Hallett C, Carroll MV, Zeller M, et al. (2012) US health policy related to hookah tobacco smoking. Am J Public Health 102: e47-51.

7. Maziak W (2008) The waterpipe: time for action. Addiction 103: 1763-1767.

8. Chaouachi K (2006) A critique of the WHO TobReg's "Advisory Note" report entitled: "Waterpipe tobacco smoking: health effects, research needs and recommended actions by regulators". J Negat Results Biomed 5: 17.

9. Maziak W (2011) The global epidemic of waterpipe smoking. Addict Behav 36 $1-5$

10. Guerrero R (2011) Exposing the myths of hookah smoking. AAP News 32:37.

11. Steentoft J, Wittendorf J, Andersen JR (2006) [Tuberculosis and water pipes as source of infection]. Ugeskr Laeger 168: 904-907.

12. Tobacco Free Initiative (2006) Tobacco: deadly in any form or disguise. World Health Organization 23-5.

13. Smith SY, Curbow B, Stillman FA (2007) Harm perception of nicotine products in college freshmen. Nicotine Tob Res 9: 977-982.

14. Al-Naggar RA, Bobryshev YV (2012) Shisha smoking and associated factors among medical students in Malaysia. Asian Pac J Cancer Prev 13: 5627-5632.

15. Shihadeh A, Saleh R (2005) Polycyclic aromatic hydrocarbons, carbon monoxide, "tar", and nicotine in the mainstream smoke aerosol of the narghile water pipe. Food Chem Toxicol 43: 655-661.

16. Cobb C, Ward KD, Maziak W, Shihadeh AL, Eissenberg T (2010) Waterpipe tobacco smoking: an emerging health crisis in the United States. Am J Health Behav 34: 275-285.

17. Knishkowy B, Amitai $Y$ (2005) Water-pipe (narghile) smoking: an emerging health risk behavior. Pediatrics 116: e113-119.

18. Griffiths MA, Harmon TR, Gilly MC (2011) Hubble bubble trouble: the need for education about and regulation of hookah smoking. Journal of Public Policy and Marketing 30:119-132.

19. Anjum Q, Ahmed F, Ashfaq T (2008) Knowledge, attitude and perception of water pipe smoking (Shisha) among adolescents aged 14-19 years. J Pak Med Assoc 58: 312-317. 
Citation: Loewen JM, Savaya MG, Mackie ZF (2016) Health Profession Student Perception on Hookah Use and Curriculum Improvement Implications. Health Care: Current Reviews 4: 157. doi: 10.4172/2375-4273.1000157

20. Harvard Mental Health Letter (2008) The hazards of hookah. Harvard Medical School 24.

21. Akl EA, Aleem S, Gunukula SK, Honeine R, Abou Jaoude P, et al. (2010) Survey instruments used in clinical and epidemiological research on waterpipe tobacco smoking: a systematic review. BMC Public Health 10:415.

22. HookaH-HookaH Company. Hookah Lounge Directory.

23. Ahmed B, Jacob P 3rd, Allen F, Benowitz N (2011) Attitudes and practices of hookah smokers in the San Francisco Bay Area. J Psychoactive Drugs 43: $146-152$.

24. Jawaid A, Zafar AM, Rehman TU, Nazir MR, Ghafoor ZA, et al. (2008) Knowledge, attitudes and practice of university students regarding waterpipe smoking in Pakistan. The International Journal of Tuberculosis and Lung Disease 12: 1077-1084

25. American Lung Association (2013) An emerging deadly trend.

26. Neergaard J, Singh P, Job J, Montgomery S (2007) Waterpipe smoking and nicotine exposure: a review of the current evidence. Nicotine Tob Res 9: 987 994.

27. Ciccone MM, Aquilino A, Cortese F, Scicchitano P, Sassara M, et al. (2010) Feasibility and effectiveness of a disease and care management model in the primary health care system for patients with heart failure and diabetes (Project Leonardo). Vasc Health Risk Manag 6: 297-305.

28. Tong EK, Strouse R, Hall J, Kovac M, Schroeder SA (2010) National survey of U.S. health professionals' smoking prevalence, cessation practices, and beliefs. Nicotine Tob Res 12: 724-733.
29. An LC, Foldes SS, Alesci NL, Bluhm JH, Bland PC, et al. (2008) The impact of smoking-cessation intervention by multiple health professionals. Am J Prev Med 34: 54-60.

30. Sheffer CE, Barone CP, Anders ME (2009) Training health care providers in the treatment of tobacco use and dependence: pre- and post-training results. $J$ Eval Clin Pract 15: 607-613.

31. Agaku IT, Ayo-Yusuf OA, Connolly GN (2014) Tobacco cessation training among dental and other health professions students in eight low- and middleincome countries. J Dent Educ 78: 75-84.

32. Rigotti NA (2011) Integrating comprehensive tobacco treatment into the evolving US health care system: it's time to act: comment on "A randomized trial of Internet and telephone treatment for smoking cessation". Arch Intern Med 171: 53-55

33. Timothy C. Chen TC, Hamlett-Berry KW, Watanabe JH, Bounthavong M, et al (2015) Evaluation of multidisciplinary tobacco cessation training program in a large health care system. Am J Health Educ 46: 165-173.

34. Shahedah A, Saleh R (2005) Polycyclic aromatic hydrocarbons, carbon monoxide, "tar", and nicotine in the mainstream smoke aerosol of the narghile water pipe. Food and Chemical Toxicology 43: 655-661.

35. Asotra K (2005) "Hooked on hookah? What you don't know can kill you." Burning Issues. Tobacco-Related Disease Research Program.

36. www.trdrp.org/docs/newsletters/2005/805nws/trprt.pd. 